$$
\begin{array}{r}
\text { Jeyla NASIBOVA* } \\
\hline \begin{array}{r}
\text { Head of Humanities Department } \\
\text { at Baku Oxford School }
\end{array}
\end{array}
$$

\section{Internet and social isolation among youth in England}

\begin{abstract}
During the last decades, technological progress and increasing globalization had a serious impact on people's daily life. The definitions, context and understanding of time, connection, relationships, identity, reality and place have been affected by innovations. Social media plays an important role in this process and it offers opportunities to the people, no matter where and who they are. This article will look at the relationship between young people in England using social media on daily basis and their social activity in the real life and time. Do people become more socially isolated while using the internet and social media in particular, or does frequent 'online' status make them more lonely? Do they prefer virtual relationships to the real ones? Does social media affect their connectivity with the people they have relationships in a real life? The article aims to answer this questions and bring deeper insight into this issue.
\end{abstract}

Keywords: Internet, social media, social isolation, technology, virtual life

\title{
Introduction
}

Diffusion and influence of the Internet are becoming obvious nowadays and it may have different effects on the society. Surely, the opportunities provided by the Internet concerning information and connectivity have changed our life. However, the more the innovations provided by Internet diffuse and people engage with them the more fear it causes in terms of leading to social isolation and replacement of face-to-face interaction. As this question became actual and

\footnotetext{
*EdD program student at Glasgow University, UK, n.jeyla@gmail.com.
} 
Jeyla Nasibova. Internet and social isolation among youth in England, p. 54-64

important, a range of researches has been done to find out the impact of the Internet on the social life of its users. However, different researchers achieved different results and made different conclusions. Some of them point out that frequent Internet use may lead to social isolation and loneliness while others found out that the opportunities provided by the development of the Internet, including social networks help people to find a friend with likely interests and overcome loneliness.

This study discusses the impact of the Internet use of students aged 18-25 in England received from ten conducted face-to-face interviews. The main focus was made on finding out if the usage of the Internet might cause social isolation and how users feel about it themselves. The results showed that for the University students in the UK, even if the frequent Internet usage may cause a slight feeling of loneliness it does not lead to the social isolation and depression. The level and frequency of the Internet use is under the control of its users and is a matter of their preference.

\section{Research and findings}

The development and diffusion of the Internet along with all the innovations and opportunities provided by it have considerably changed lives of millions people around the world. This change influenced many areas of everyday routine including education, business, economic and political spheres, leisure and social life. Especially the progress of Informational Technologies in terms of allowing connectivity to people without any time and space limitations is ongoing and provides more and more opportunities to communicate and interact globally. As mentioned Webster (2001) life is changing all the time and people do not expect things to remain the same for even next several years. ${ }^{1}$

The Internet became an inherent part of daily life, but some researchers noted that frequently and heavy Internet use may lead to the replacement of normal social relations as the Internet could be considered as the predominant part in the social lives of many of its users (Hamburger, Ben-Artzi, 2002). ${ }^{2}$ Social networks

\footnotetext{
${ }^{1}$ Webster, F. Culture and Politics in the Information Age: a new Politics?, London and NY, Routledge, 2001.

2 Hamburger, Y.A., Ben-Artzi, E., The Relationship between extraversion and neuroticism and the dierent uses of the Internet. Computer in Human Behavior, 16, 2000, pp. 441-445.
} 
become more and more popular every day, people of different age, nationalities, professions and with diverse interests becoming engaged with hundreds of online social communities and virtual groups. For instance, Facebook has more than 800 millions of active your, more of $50 \%$ of them $\log$ on to the website every day, average user is connected to 80 community pages, events and groups, and more than 350 million users currently logged in to Facebook via their mobile phones (www.facebook.com/press/info.php?statistics, date of access 20.09.2011). Facebook is one of the most wide-spread and popular social networks, however, there are a lot of other which people participate in. Increasingly heavy use of the Internet caused fear of the social isolation and loneliness among the users, who spend considerably a lot of time during the day online and less hours with their friends and families. So, even if people spend this time being connected to others via virtual networks they physically spend it alone. From one point of view, these circumstances may lead to social isolation, which can not only affect normal social life but also might be risky for the health of those who experience it (House, 2001) ${ }^{1}$.

People find their lives influenced by collectivities that have nothing to do with physical presence. So, the new type of community - the virtual community or the community on computer networks may affect real life community. However, it becomes more obvious that virtual communities can be considered as a new modern supplement on the cultural scene (Porter, 1997) ${ }^{2}$. Different reasons made those virtual communities as popular as they are today including chance to shape the identity, find and develop new relationships, join groups and discuss diverse topics with individuals with likely interests, share opinions, thoughts, ideas, photos and videos, play with real people, no matter where they are and other. However, online communities can hardly displace face-to-face contact where people laugh, smile and grumble at each other ${ }^{3}$ (Wellman, 2004). But there might be a risk that those face-to-face communications and collaborations can happen much rarely and people may become socially isolated. It depends on the personalities and on the level of

${ }^{1}$ House S. J., Social Isolation Kills, but How and Why?, Psychosomatic Medicine 63:273-274, American Psychosomatic Society, 2001.

${ }^{2}$ Porter D., Internet Culture, London and NY, Routledge, 1997.

${ }^{3}$ Wellman, B., Quan-Haase A., Hyperconnected Net Work: Computer Mediated Community in a High-Tech Organisation, Collaborative Community in Business and Society, USA, 2004. 
Jeyla Nasibova. Internet and social isolation among youth in England, p. 54-64

development and diffusion of new media and Informational technologies. For instance, in USA and Japan the risk of suffering from social isolation for heavy Internet users is higher than in the $\mathrm{UK}^{1}$ (Turkle, 2011). However, as the progress of new media and Internet is an ongoing process the situation can change any time.

The development of new media has an obvious impact on the social interaction of people of different ages. However, among the young population, for instance, students' participation in "virtual communities" and social networking are extremely popular nowadays. The internet itself and all the tools which made it easier to connect to give young people a lot of opportunities; and, as it can be seen from the practice, the more developed and improved are the tools of the new media and connectivity, the more innovations it offers to the public, the more popular and widespread they become.

The term "virtual life" is also becoming more abundant along with the progress of informational technologies/new media. 'Virtual life' or 'virtual reality' is a space in which information and data are not stored in the person's brain but in computer networks which enable human communication and activity at a distance ${ }^{2}$. There is a huge range of opportunities provided by virtual life and hence a lot of reasons why people prefer to spend a lot of time "online". Virtual communities, chats, discussion groups are one of the most popular "places" for social interaction. According to some particular observations ${ }^{3}$ (McNeeley, 1997, as cited in Flew, 2002, p.82) the reasons why people take part in online discussion groups are the following. First of all, it is the chance to build up a friendship and relationships which can be perceived as being much more difficult to form in the "off-line" community. Secondly, the opportunity to play with personas also plays an important role. Thirdly, there is a chance to circulate new ideas between a group of people with the same interests and the opportunity to find people who share the same ideas and interests, even if they appear as odd or strange for others. People also participate in online communities because of the chance to find romantic relationships and because this participation enables the opportunity for those who feel insulated

\footnotetext{
${ }^{1}$ Turkle, S., Alone Together, NY, Basic Books, 2011.

${ }^{2}$ Rheingold, H., The Virtual Community, New York, Harper Perennial, 1994.

${ }^{3}$ Flew T, New Media, Oxford University Press, 2002.
} 
or persecuted by society to express their ideas and disseminate opinions, what they can not do via more mainstream media channels.

These reasons seem to express that there is some dissatisfaction with the limitations of "real" communities that increase the involvement in virtual ones.

According to another research (Godwin, 1998, p.38, as cited in Flew, 2002) there are ten main principles which make online communities work, and those are the use of software that promotes group discussion, does not impose a length limitation on postings, front load your online community with diverse and talkative people, lets users resolve their own disputes, promotes institutional memory, through archiving of previous discussion threads, promotes continuity by keeping old postings available, acts as a host to one or more interest groups, commits the online community to the principle of maintaining public spaces for public communication and public events, to be prepared to confront the users with a crisis, as a reason for continuing to participate ${ }^{1}$.

Even if most of these reasons are still playing a huge role in people's participation in virtual networks, during the last decade new media went through the impressive progress and there are many innovations and new opportunities in virtual life, so reasons why online networks attract people and they start to use them more and more may also be different today. And the more time people spend staying "online" for various purposes, the more they spend it physically alone. For instance, while someone is using Facebook, chatting with friends and viewing their profile pages and photos, he/she can feel himself/herself interconnected with many people simultaneously, however, it all is happening while one is alone in his/her room, spending hours in front of the computer, typing. Not even speaking. So, the question is, does the development of the new media and online networks give people the opportunity to become a part of the global community and stay interconnected or it may lead to social isolation?

To bring insight into that question I have conducted a survey and face-to-face interviews among university students in England. Each interviewer provided a researcher with the comprehensive and relevant for the study information which made it possible to give several statements with regards to the topic being researched after analysis and discussion of the data. The questions of the interview were

\footnotetext{
${ }^{1}$ Flew T. New Media, Oxford University Press, 2002.
} 
subdivided into three types - background, usage of the Internet and virtual networks and feelings and perception in regards with the Internet use and social isolation.

Most of the respondents started using the internet when they were at school, only 3 out of 10 reported that they became Internet users when they finished school, between 17 and 19 years old. The main purpose of engaging with the Internet was access to the information, both general with regards to the personal interests and useful for the studies. For the present period of time, their Internet usage considerably increased. From this survey I found that at the average approximately four hours and a half students spend online every day. Three participants mentioned that they use the Internet all day long through their mobile devices. All ten respondents participate in social networks, and all of them give preference to Facebook, and eight people claimed that social networking is one of the main reasons why they go online and use the Internet in general. However, all ten respondents mentioned that the main purpose of going online for them is keeping in touch with their friends and families. So, as was mentioned by Baym (2010) in the second chapter, communicating and interacting with people through the Internet has no distance/space limitations. According to the result of the research I have done, this opportunity really is the first reason why people, especially students, go online ${ }^{1}$. As most of the participants have friends and family abroad, they use Internet to stay in contact with them, and as was argued Turkle (2011) in no longer depends on the distance between them ${ }^{2}$.

It would be important to note that students, who use social networks and other online tools to keep in touch and communicate with their friends and families, use them first of all for social purposes. Apparently, in this case, they are not becoming isolated from society, vice-versa, they use the opportunity to communicate with real people, who they physically are not able to meet in the real life because of the distance. Taking this into account it can be hypothesized that Internet may increase social interaction for those who have a lot of friends and family around the world. As mentioned van Dijk (2006) spending time alone physically but commu-

\footnotetext{
${ }^{1}$ Baym, N.K. Personal Connections in the Digital Age, Polity Press, UK, 2010.

2 Turkle, S., Alone Together, NY, Basic Books, 2011.
} 
nicating online also can be totally social ${ }^{1}$. Hardly, people can feel themselves isolated during these communications; however their perception related to this question will be discussed in details below.

The participants were asked to name other from the social networking main reasons if there are any why they engage with the Internet. The entertainment including watching movies, playing games and listening to the music and personal interests were mentioned six times, email four times, studies and news three times. Eight out of ten participants noted checking the social networks, especially Facebook every day, mostly few times a day, and they often go online just to check them. Nine of them use their mobile devices to have the access to the Internet during the day and check social networks. Only two respondents said that they check them when they have free time, about one time per week. However, one person mentioned that he check Facebook about 15 times per day, which as he pointed out himself might be regarded as considerably heavy use of the Internet.

From the findings introduced above can be seen that within a considerably young population of the United Kingdom the social networks, especially Facebook, became really popular, much more than any other networks. Several times during the interviews Twitter and Skype were also mentioned, however not by all of the respondents and not in the first place. Most of the respondents named social networks as one of the main purposes of using the Internet. If they started to use the Internet while they were at school, for instance, to find some information relevant for their lessons or to look through some interesting for the websites, after the appearance and development of social networks the time they usually spend online increased. People go online several times a day just to check if they have some new 'notifications' which means that their friends on Facebook posted something new, or someone commented or 'liked' their photos or messages, or, maybe someone sent to them a personal message or invited to some event. Thus, the social networks, especially Facebook, give people a chance to follow lives of their friends, to stay in touch with them and be informed about important things happening to their relatives and friends, especially if they are abroad and the most convenient way to communicate with them is via the Internet. If they often update

\footnotetext{
${ }^{1}$ Van Dijk, Jan A.G.M, The Network Society, London \& Dehli, SAGE Publications, 2006.
} 
Jeyla Nasibova. Internet and social isolation among youth in England, p. 54-64

the profile pages, other can see what events they had attended, and as one of the innovations on Facebook, even see the places where they had checked in.

The important point is the fact that $90 \%$ of the people been interviewed log on Facebook through their mobile phones several times a day. It shows how the development of the new media influence people's participation in social networks, makes it much easier to stay connected as long as one wishes and break the limitation of space and time in this case. People go online and communicate via their mobile phones at any time and any place. ${ }^{1}$ The only one participant, Mary, is using the Internet only through the computer but not mobile phone, but from her background and answers on other questions became obvious that she is not a fan of social networks at all, she uses them just to keep in touch with friends and family, but she believes that staying online for a long time can be considered as a wasting of time and prefers face-to-face contact with all other types of communication.

I have also found out that students use the Internet frequently because it provides them with easier and cheaper entertainment. Three respondents mentioned that they frequently watch movies online. The access to the range of movies and music that Internet allows is one of the important reasons why people spend time using it. Especially or students it might be a great opportunity, as they watch the films and listen to the music for very low costs or even for free, and they can do it from their homes. Except from music and movies, the Internet makes it possible to follow your interests and watch most of the shows and TV programs, at any time you are available and have free time. For instance, one of the respondents, Nicolas, mentioned that he usually watches football online. Thus, the Internet also allows people to watch shows they like not in a 'live' regime on TV but when people have free time. If students are busy with their exams and assessments some periods of time, they know that they will be able to watch particular shows they like online, on official websites or YouTube.

Free and easy access to the all recent news in the world, including political, social, economic, news about celebrities and many others, available on all languages, as showed survey, also encourage individuals to spend time online.

The question about the opportunity to meet new people with likely interests and find and develop relationships online has also been raised in the interviews.

\footnotetext{
${ }^{1}$ Castells M., Internet Galaxy, Oxford University Press, 2001.
} 
As was mentioned in the second chapter, the relationships created online usually do not become really serious, but sometimes, meaningful relations can be created via online connections ${ }^{1}$ (Baym, 2010). However, what pointed out four respondents was that virtual relationships should not be called serious ones before people meet in the real life, no matter if they are romantic, social or professional. Three other participants do not believe that online relationships can be considered as real ones. So, as it can be seen, the virtual life offers really attractive opportunities and participants are happy to be involved in the processes and networks, which provide this innovations and possibilities. However, so far none of them sounded like extremely addicted to the Internet person who has a poor social life. Even while getting as much as they can from the Internet they do not prefer virtual life to the real one. So what else can virtual life offer to the people to make them seriously addicted and dependent from itself? As showed results of this research, not all people think that online networks and virtual life, in general, can give them anything that they are not able to get into the real life.

\section{Conclusion}

This research showed that student in England mostly use the Internet to engage with social networks, so they go online mostly for virtual social activities. The fear that virtual communities and communication may in the future replace the real ones and therefore, lead to the social isolation of the Internet-addicted people is not relevant to the situation in England. A considerable amount of students in the UK have families and friends abroad, so they spend a lot of time online to communicate with them. In sum, the impact of the Internet use on the social life of university student in the UK is not negative. In this case, there is no threat of the social isolation caused by the Internet use and participation in social networks. Inversely, the opportunities provided by the Internet enrich and amend the social life of many of them, as they allow a different type of social interaction without space and time limitations and at the same time do not affect real social life and activities.

\footnotetext{
${ }^{1}$ Baym, N.K. Personal Connections in the Digital Age, Polity Press, UK, 2010.
} 


\section{References} 2010.

1. Baym, N.K. Personal Connections in the Digital Age, Polity Press, UK,

2. Castells M. Internet Galaxy, Oxford University Press, 2001.

3. Flew T, New Media, Oxford University Press, 2002.

4. Hamburger, Y.A., Ben-Artzi, E., The Relationship between extraversion and neuroticism and the dierent uses of the Internet. Computer in Human Behavior, 2000, 16, pp. 441-445.

5. House S. J., Social Isolation Kills, but How and Why?, Psychosomatic Medicine 63:273-274, American Psychosomatic Society, 2001.

6. Porter D., Internet Culture, London and NY, Routledge

7. Rheingold, H., 1994, The Virtual Community, New York, Harper Perennial, 1997.

8. Turkle, S., Alone Together, NY, Basic Books, 2011.

9. Van Dijk, Jan A.G.M, The Network Society, London \& Dehli, SAGE Publications, 2006.

10. Webster, F., Culture and Politics in the Information Age: a new Politics?, London and NY, Routledge, 2001.

11. Wellman, B., Quan-Haase A., Hyperconnected Net Work: Computer Mediated, 2004.

12. Community in a High-Tech Organisation, Collaborative Community in Business and Society, USA.

\section{Ceyla Nosibova}

\section{Ingiltorado ganclor arasında internet vo social tocrid olunma (xülasa)}

Son onilliklar arzinda texnoloji inkişaf va qloballaşmanın artması insanların gündalik həyatına ciddi tasir etmişdir. Zamanın tayinatl, konteksti va anlaşılması, alaqalar, münasibətlar, şaxsiyyat, gerçəklik va məkan yeniliklarin təsirina uğramışdır. Bu prosesda sosial media mühüm rol oynayır va insanlara kimliyindən vo harada olmaqlarından asılı olmayaraq imkanlar təklif edir. Bu maqalədə Ingiltərado yaşayan gündəlik sosial mediadan istifado edən gənclorin real həyatlarında va zamanlarında sosial hayatdakı faaliyyətlari arasındakı alaqəni nəzərdən keçirilir. Insanlar internetdon va xüsusila da sosial mediadan istifadə edərkən daha çox sosial cəhətdan tacrid olunurlar, yaxud mütəmadi "online" vaziyyatda olmaları onlarl daha da yalnız edir? Onlar virtual münasibəti real münasibətlordən üstün tuturlar? Sosial media insanların real həyatında münasibətdə olduqlart insanlarla slaqalorina təsir edirmi? Maqala bu suallara cavab tapmağl va bu masalaya daha dərin bir baxış yetirmayi qarşısına maqsad qoymuşdur. 
Açar sözlor: Internet, sosial media, sosial tacrid olunma, texnologiya, virtual hayat.

\section{Джкейла Насибова}

\section{Интернет и социальная изоляция среди молодежи в Англии (резюме)}

В последние десятилетия технический прогресс и растущая глобализация оказали серьезное влияние на повседневную жизнь людей. Понятия, контексты и понимание времени, контакты, взаимоотномения, идентичности, реальность и пространство были затронуты инновачиями. Важную роль в этом процессе играют социальные медиа и возможности, которые они предлагают людям, независимо от того, где они находятся, и кем являются. В настоящей статье рассмотривается ежедневная взаимосвязь с использованием социальных сетей среди молодёжи Англии и их социальная активность в реальной жизни и повседневной занятости. Становятся ли люди более сочиально изолированными при использовании интернета и соииальных сетей, в частности, или нахождение в постоянном статусе «онлайн» делает их более одинокими? Предпочитают ли они виртуальные отношения реальныл? Влияют ли сочиальные медиа на их связи с людьми, с которыми у них есть отношения в реальной жизни? Цель данной статьи - ответить на эти вопросы и глубже разобраться в этой проблеме.

Ключевые слова: Интернет, социальная медиа, социальная изоляция, технология, виртуальная жизнь. 